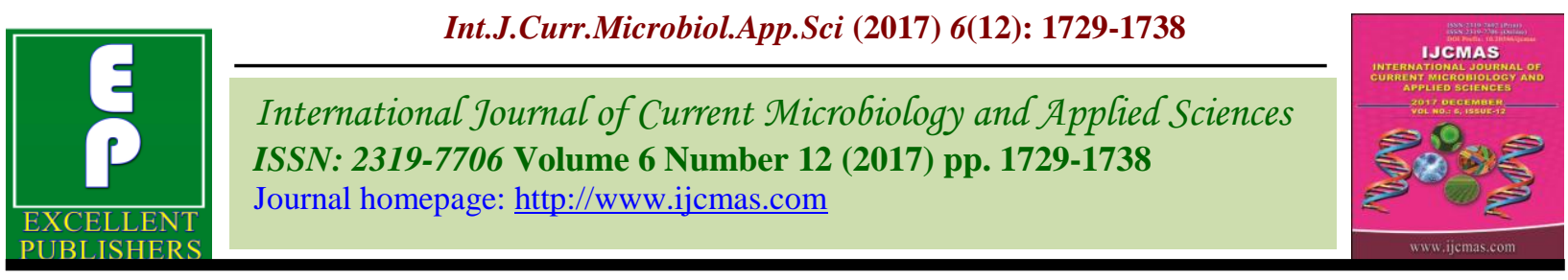

Review Article

https://doi.org/10.20546/ijcmas.2017.612.196

\title{
Organic Sugarcane: A Review
}

\author{
Shilpa V. Chogatapur*, Vishwajith and Reshma Sutar \\ Department of Agronomy, College of Agriculture, Dharwad, University of Agricultural \\ Sciences, Dharwad, Karnataka, India \\ *Corresponding author
}

\begin{tabular}{|c|c|}
\hline & A B S T R A C T \\
\hline & \multirow{6}{*}{$\begin{array}{l}\text { Sugarcane (Saccharum officinarum L.) is one of the important commercial crops of India. } \\
\text { Sugar is the second largest agro based industry in India after cotton textile industry. The } \\
\text { Indian sugar industry has a turnover of Rs. } 500 \text { billion per annum and it contributes almost } \\
\text { Rs. } 22.5 \text { billion to the central and state exchequer as tax and excise duty every year. The } \\
\text { sugar industry provides livelihood to } 35 \text { million growers, factory workers and their } \\
\text { dependents, which constitute about } 7.5 \text { per cent of the rural population. The sugar industry } \\
\text { employs } 2 \text { million workers and also provides substantial indirect employment through } \\
\text { various ancillary activities. Sugar and its byproducts play a pivotal role in the agro- } \\
\text { industrial economy and share nearly two per cent of the GDP. The industry not only } \\
\text { generates power for its own requirement but surplus power for export to the grid based on } \\
\text { byproduct bagasse. It also produces ethyl alcohol, which has industrial and potable uses, } \\
\text { and ethanol is an eco-friendly and renewable fuel for blending with petrol. Organic } \\
\text { farming systems have attracted increasing attention over the last one decade because they } \\
\text { are perceived to offer some solutions to the problems currently besetting the agricultural } \\
\text { sector. Organic farming has the potential to provide benefits in terms of environmental } \\
\text { protection, conservation of nonrenewable resources and improved food quality. }\end{array}$} \\
\hline Keywords & \\
\hline $\begin{array}{l}\text { Sugarcane, Organic } \\
\text { nutrition, Pest } \\
\text { management. }\end{array}$ & \\
\hline Article Info & \\
\hline $\begin{array}{l}\text { Accepted: } \\
\text { 15 October } 2017 \\
\text { Available Online: } \\
\text { 10 December } 2017\end{array}$ & \\
\hline & \\
\hline
\end{tabular}

\section{Introduction}

The challenge of feeding an ever increasing population coupled with the changing environmental situation demands concerted efforts to address the food and nutritional insecurity of the nation. In agricultural sector, sugarcane plays a key role in Indian economy by contributing more to the national income through excise duty and payment to cane growers. India's share in the world sugar production was 17 per cent in 2014-15 (Singh and Katiyar, 2016). About 35 million farmers grow and depend on sugarcane for their livelihood and an equal number of agricultural labourers earn their bread by working in sugarcane farms. The main product of sugarcane is sucrose, which accumulates in stalk internodes (Paturau, 1984). It is extracted and purified in specialized mill factories which is used as an important sweetener in human diet, a raw material in food industries or fermented to produce ethanol being a low polluting fuel. Sugarcane products include table sugar, molasses, bagasse and ethanol. In India it is grown on an area of 4.94 million hectare with a production of 346.72 million tonne and an average productivity of $70.05 \mathrm{t} \mathrm{ha}^{-1}$. To meet the expected combined demand posed by 
anticipated population and consumption increase, along with the other challenges, India will have to produce 51 million tonne of white sugar by 2050 from the present 27.7 million tonne which will be possible only with a quantum jump in sugarcane productivity and sugar recovery. It is imperative that new methods and production practices needs to be adopted to suit the increasing demands of stakeholders, in order to overcome the various challenges.

The unsustainability of modern agricultural practices have led farming communities the world over to look for alternatives. The majority of these alternatives indicate a return to traditional, eco-friendly practices; organic farming is one among them. Organic farming is basically a holistic management system which promotes and improves the health of agro ecosystem related to biodiversity, nutrient biocycles, soil microbial and biochemical activities. It emphasizes management practices involving substantial use of organic manures, green manuring and management of pests and diseases through the use of nonsynthetic pesticides and practices. Organic farming over the last few decades has proved to be successful; but the differences in culture, ecology and geographical factors necessitate adoption of situation-specific principles and techniques. In the developing countries like India, the share of organic farming around 2 per cent only (included certified and wildlife).

\section{Nutrient management in organic sugarcane}

Organic sources of nutrients not only help in supplementing the nutrients to sugarcane but also maintain favourable physical, chemical and biological soil environment. Long term fertilizer experiments have indicated the need for basal application of FYM for maintaining optimum fertility status. Sugarcane trash is one of the most commonly available farm wastes in sugarcane growing areas. Cane trash accounts for 10-12 per cent of the cane harvested. Press mud, one of the important organic sources emanating from sugar industry, is a good source of nutrients. Many workers have studied the effect of press mud as a source of plant nutrients. It also enriches the soil in terms of organic matter which improved the physical properties of the soil especially the water transmission characteristic of soil. Increase in the available nitrogen with application of bio-compost and farmyard manures may be attributed to the incorporation of organic matter which enhances the multiplication of microbes by incorporation of different organic sources for the conversion of organically bound $\mathrm{N}$ to in organic form (Sinha et al., 2014).

\section{FYM}

Sharma et al., (2005a) reported that FYM application on equal $\mathrm{N}$ basis increased the shoot population, number of millable canes and yield over others without remarkable change in sugar content of cane. Gana and Busari (2006) showed that cane yields were generally lower under the legume-treated soils (38.7-53.4 $\mathrm{t} \mathrm{ha}^{-1}$ ) when compared to yields recorded under FYM (58.6 -70.1 $\left.\mathrm{t} \mathrm{ha}^{-1}\right)$ or even inorganic fertilizers (55.7- $\left.66.9 \mathrm{t} \mathrm{ha}^{-1}\right)$. The highest mean germination per centage (43.89), number of tillers per hectare (167087), number of millable canes per hectare (125055), yield per hectare (78.85 t), sucrose per centage in juice (19.05) and purity coefficient $(86.58 \%)$ were obtained with FYM + groundnut cake + urea treatment (Vedprakash et al., 2009). Application of FYM equivalent to $\mathrm{N}$ recorded significantly superior yield (58.51 t ha-1) over the control treatment (Yogananda et al., 2014a). Yogananda et al., (2014b), carried out research at VC farm Mandya and reported that the sugarcane responded positively with the increasing levels of FYM and Bio- 
digester liquid manure. Maximum cane yield (82.18 $\left.\mathrm{t} \mathrm{ha}^{-1}\right)$ was observed with UAS package followed by $31.25 \mathrm{t}$ FYM with biodigester liquid equivalent to $312.5 \mathrm{~kg} \mathrm{~N}^{-1}$ (76.79 $\mathrm{t} \mathrm{ha}^{-1}$ ) and was lower with absolute control (46.10 $\mathrm{t} \mathrm{ha}^{-1}$ ). Similar trend were also observed with other yield parameters. The CCS per cent was at par among the treatment combinations (Table 1).

\section{Vermicompost}

Giraddi (1993) stated that vermicompost contained $0.8,1.1$ and 0.5 per cent $\mathrm{N}, \mathrm{P}_{2} \mathrm{O}_{5}$ and $\mathrm{K}_{2} \mathrm{O}$, respectively. In comparison with FYM, the vermicompost contained two times more $\mathrm{N}$ and four times more $\mathrm{P}_{2} \mathrm{O}_{5}$ and $\mathrm{K}_{2} \mathrm{O}$. Yadahalli (2008) reported that application of neem cake helped for getting significantly higher germination $(68.5 \%)$ than other amendments. However, neem cake amended treatment recorded significantly low set rot $(27.83 \%)$, followed by vermicompost $(42.72 \%)$, press mud $(43.45 \%)$ and FYM $(46.40 \%)$ which recorded on at par developments of set rot.

\section{Green manures}

Inclusion green manures of in the cropping system improved the crop yield and sustain the soil fertility. This might be due to addition of organic matter by green manure crop, which on decomposition supplied nitrogen as well as other macro and micronutrients during the course of the crop growth. Green manure residues having wider $\mathrm{C}$ : $\mathrm{N}$ ratio favoured by immobilizing higher percentage of applied fertilizer nitrogen initially and then slowly releasing the same over a period of time. Contribution of organic matter, which might have helped in utilizing, increased available nitrogen as well as phosphorus on decomposition. The organic acids produced during decomposition also favoured solubilization of native soil phosphorus and retaining more available phosphorus for longer period resulting in higher cane yield. Finally the losses. of nitrogen were minimized and phosphorus availability increased by daincha green manure incorporation.

\section{Pressmud}

Parameswaran et al., (1995), observed 0.40 per cent $\mathrm{N}, 0.13$ per cent $\mathrm{P}$ and 0.40 per cent $\mathrm{K}$ in sugarcane trash with $\mathrm{C}: \mathrm{N}$ ratio of 113:1 while press mud contained 0.90 per cent $\mathrm{N}$, 1.50 per cent $\mathrm{P}$ and 0.5 per cent $\mathrm{K}$ as reported by Kumaraswamy (1995). Press mud contained approximately 1.0 to 1.5 per cent $\mathrm{N}, 2.5$ to 3.5 per cent $\mathrm{P}_{2} \mathrm{O}_{5}$ and 0.5 to 0.8 per cent $\mathrm{K}_{2} \mathrm{O}$ and organic carbon of 35 to 37 per cent (Kale, 1981). Pressmud is the byproduct of sugar industry and can be used as organic manure. Pressmud also provides most of the essential elements beside $22-25 \%$ organic carbon and its application also reclaim the problematic soil. Pressmud is produced to the tune of $3 \%$ of the total weight of cane crushed. In India in 2003-04, 287.38 M tons of sugarcane is produced out of which 194.4 $\mathrm{m}$ tons of total cane was crushed which has produced 5.2 $\mathrm{M}$ tones of press mud. This sizeable quantity can be an important source of organic manure. The fresh press mud, when incorporated in the soil may cause burning in the crop. The application of decomposed pressmud in combination with inorganic fertilizers could be more beneficial. Yadav (1995) reviewed the benefits of application of sulphitation pressmud cake in sugarcane and other crops. Saini et al., (2006a) reported that PMC at $10 \mathrm{t} \mathrm{ha}^{-1}$ coupled with biofertilizers (PSB) at $2.5 \mathrm{~kg}$ $\mathrm{ha}^{-1}$ exhibited significantly higher shoot population than that of recommended NPK. Shankaraiah and Kalyanamurthy (2005) reported significant improvement in shoot population with integrated use of press mud at 15 tonnes per hectare at recommended 
fertilizer level. Application of 10 tonnes of press mud cake per hectare with recommended $\mathrm{P}$ and $\mathrm{K}$ and PSB increased shoot population and number of millable canes (Sharma et al., 2009).

\section{Trash mulch}

Crop residue incorporation in soil is very important source of organic manure. Sugarcane crop produces 10-12 tons of dry leaves per ha per year which contains appreciable amount of NPK and other micro and secondary nutrients. In India about $282 \mathrm{M}$ tons of sugarcane is produced of which trash contributes $10 \%$ of total biomass. The soil incorporation of sugarcane trash releases nutrients after decomposition. This may build up the nutrients in soil and changes physical properties of the soil. With decomposition of trash in the soil, the organic acids are produced which would help in solublilzing the nutrient in the soil and increasing their availability. The application sugarcane trash @ 3t/ha when compared with no trash increased the available $\mathrm{K}$ in the soil from 329 to $338 \mathrm{~kg} / \mathrm{ha}$ and 303 to $338 \mathrm{~kg} / \mathrm{ha}$ in soil samples collected in September and January, respectively (Kumar and Sagwal, 1998).

\section{Bio-Fertilizers}

Studies conducted in different part of India have shown that the use of different biofertilizers viz., Azotobacter, Azospirillum and phosphorus fixing bacteria (Bacillus magatherium) alone or in combined use of these micro-organism significantly increased the sugarcane and sugar yields. The combined use of these micro-organisms always recorded increase in yields over their application alone.

\section{Soil health and microbial activity}

Significant improvement in the uptake of nutrient $(\mathrm{N}, \mathrm{P}$ and $\mathrm{K}$ ) was recorded due various organic nutrition modules compared with that of control both for autumn and spring planted sugarcane crops. During both the seasons, significantly highest quantities of nitrogen (227.7 and $185.4 \mathrm{~kg} / \mathrm{ha}$ for autumn and spring cane) were removed under SPM 10 t/ha + FYM 10 t/ha application compared with the uptake of 152.6 and $141.7 \mathrm{~kg} / \mathrm{ha}$ nitrogen under control condition.

Phosphorus uptake was also found significantly highest (17.8 and $13.4 \mathrm{~kg} / \mathrm{ha})$ under this treatment for autumn as well as spring cane (Srivastava et al., 2008). Application of 100 per cent $\mathrm{N}$ through organics brought about substantial increase in organic carbon content of the soil.

The highest enhancement in organic carbon content $(0.65$ over initial $0.40 \%)$ at ratoon harvest was recorded in the treatment receiving 100 per cent $\mathrm{N}$ through organic + biofertilizers + inter cropping of legume with rhizobium + pests/diseases control by either synthetic pesticides or biopesticides (Singh and Srivastava, 2011).

Srivastava et al., 2008 organic nutrition for sugarcane effectively improved the physical as well as microbial properties of the soil and significantly improved the organic carbon content of the soil.

The increase in soil-organic $\mathrm{C}$ at sugarcane harvest over the initial content was the highest (70.73\%) due to application of FYM 20 t/ha + Trichoderma viride + lentil intercropping (1: 2) or SPM 10 t/ha + lentil intercropping $(1: \quad 2)$ in autumn sugarcane, and corresponding highest increase $(65.9 \%)$ due to the application of SPM 10 t/ha + Azotobacter inoculation in spring sugarcane. High content of cellulosic compounds in SPM as well as crop residues must be responsible for substantial increase in the organic carbon content of the soil under these treatments (Table 2). 
Table.1 Nutrient contents in different organic manure

\begin{tabular}{|l|l|l|l|l|l|l|l|l|l|l|l|}
\hline \multirow{2}{*}{$\begin{array}{l}\text { Organic } \\
\text { manures }\end{array}$} & \multicolumn{3}{|l|}{ Major nutrients (\%) } & \multicolumn{3}{l|}{ Secondary nutrients (\%) } & \multicolumn{3}{|l|}{ Micro-nutrients(mg/kg) } \\
\cline { 2 - 12 } & $\mathbf{N}$ & $\mathbf{P}$ & $\mathbf{K}$ & $\mathbf{C a}$ & $\mathbf{M g}$ & $\mathbf{S}$ & $\mathbf{Z n}$ & $\mathbf{F e}$ & $\mathbf{C u}$ & Mn \\
\hline FYM & 0.6 & 0.30 & 0.70 & 0.20 & & & 20 & 180 & - & 45 \\
\hline $\begin{array}{l}\text { Green } \\
\text { manure }\end{array}$ & 2.3 & 0.40 & & & & & 17 & 140 & 3 & 80 \\
\hline Press mud & 2.8 & 0.56 & 0.34 & 2.6 & 2.0 & 3.8 & 140 & 800 & 43 & 105 \\
\hline $\begin{array}{l}\text { Pressmud } \\
\text { compost }\end{array}$ & 2.4 & 1.6 & 1.50 & 5.8 & 1.8 & 3.0 & 234 & 5227 & 223 & 334 \\
\hline
\end{tabular}

Source: Kumar et al., (2005)

Table.2 Effect of organic nutrition on soil health indicators at harvest of sugarcane crop

\begin{tabular}{|c|c|c|c|c|c|c|}
\hline \multirow[t]{2}{*}{ Treatment } & \multicolumn{2}{|c|}{$\overline{S O C ~(\%)}$} & \multicolumn{2}{|c|}{$\begin{array}{l}\mathrm{SMBC}(\mathrm{mgC}- \\
\left.\mathrm{CO}_{2} / \mathrm{kg} \mathrm{soil} / \mathrm{day}\right)\end{array}$} & \multicolumn{2}{|c|}{$\begin{array}{l}\text { SMBN (mg N- } \\
\text { NH }^{4} / \mathrm{kg} \mathrm{soil/day)}\end{array}$} \\
\hline & Autumn & Spring & Autumn & Spring & Autumn & Spring \\
\hline SPM 10 t/ha+Azotobacter & 0.70 & 0.68 & 419 & 354 & 12.42 & 9.49 \\
\hline $\begin{array}{l}\text { FYM } 20 \mathrm{t} / \mathrm{ha}+\text { Trichoderma viride }+ \\
\text { I.C } *\end{array}$ & 0.70 & 0.60 & 396 & 335 & 17.33 & 12.39 \\
\hline SPM 10 t/ha + FYM 10 t/ha & 0.54 & 0.57 & 396 & 315 & 19.87 & 9.49 \\
\hline SPM 10 t/ha + Intercropping & 0.70 & 0.66 & 293 & 315 & 12.25 & 11.05 \\
\hline FYM 20 t/ha + Acetobacter & 0.68 & 0.56 & 356 & 295 & 8.73 & 9.74 \\
\hline Control (no manure) & 0.46 & 0.43 & 232 & 255 & 7.78 & 8.87 \\
\hline S. Em \pm & 0.026 & 0.024 & 2.91 & 2.87 & 0.46 & 0.49 \\
\hline $\mathrm{CD}(\mathrm{P}=0.05)$ & 0.08 & 0.08 & 9.2 & 8.9 & 1.36 & 1.52 \\
\hline
\end{tabular}

Srivastava et al., 2008

Table.3 Losses in sugarcane production due to different insects and pests in India

\begin{tabular}{|l|l|l|}
\hline Name of Pest & \% Reduction in cane yield & $\begin{array}{l}\text { \% Reduction in sugar } \\
\text { recovery }\end{array}$ \\
\hline Early shoot borer & 22 to 33 & 2 CCS \\
\hline Internode borer & 34.88 & $1.7-3.07$ \\
\hline Top shoot borer & $21-37$ & $0.2-4.1$ \\
\hline Stalk borer & upto 33 & $1.7-3.07$ \\
\hline White Fly & 80 & $1.4-1.8$ \\
\hline White grub(H) & 100 & $5.0-6.0$ \\
\hline Whiter grub(L) & 33 & complete drying \\
\hline Termite & 22.27 & 4.5 \\
\hline Rodents & 7 to 39 & - \\
\hline Sugarcane woolly aphid & - & $1.2-3.43$ \\
\hline
\end{tabular}


Table.4 Economic threshold of some major pests in Sugarcane

\begin{tabular}{|l|l|}
\hline Name of the pest & Economic threshold level \\
\hline Early shoot borer & $15.0-22.8 \%$ for late variety, 16.8\% for early variety. \\
\hline Pyrilla & $3-5$ individuals / leaf or one egg mass 1 leaf + \\
\hline Stalk borer & 17 bored internodes 1 row of 6 m. Length \\
\hline Internode borer & 16.15 to 28.39 bored canes 1 row of 6 m. length \\
\hline Top borer & $15-22 \%$ incidence \\
\hline White grub & 15 beetles / host tree \\
\hline Rodents & 15 live burrows / ha. \\
\hline
\end{tabular}

Table.5 Abundance of sugarcane borers and general predators in polyculture experimental plots shortly after the harvest of intercrop

\begin{tabular}{|l|l|l|l|}
\hline \multirow{2}{*}{ Intercrop } & \multicolumn{2}{|l|}{ Mean incidence $(\%)$} & Predator no. $^{\text {plot }}{ }^{-1}$ (Spiders and coccinellids) \\
\cline { 2 - 4 } & Shoot borer & Top borer & \\
\hline Blackgram & $1.7(1.3)^{\#} \mathrm{a}$ & $0.2 @$ & $2.0(1.6) \mathrm{a}$ \\
\hline Cowpea & $2.2(1.4) \mathrm{a}$ & 0.0 & $0.3(0.9) \mathrm{b}$ \\
\hline Greengram & $3.0(1.8) \mathrm{a}$ & 0.0 & $1.0(1.2) \mathrm{ab}$ \\
\hline Soybean & $2.6(1.5) \mathrm{a}$ & 0.3 & $2.0(1.6) \mathrm{a}$ \\
\hline Control & $3.9(2.1) \mathrm{a}$ & 0.1 & $2.7(1.8) \mathrm{a}$ \\
\hline S.Em \pm & 0.39 & & 0.18 \\
\hline
\end{tabular}

Srikanth et al., (2000)

\#Figures in parentheses are: $\sqrt{\mathrm{X}+0.5}$ transformed values

! Means followed by the same letter in a column are not significantly different $(\mathrm{P}>0.05)$ by DMRT

@Data are not subjected to ANOVA due to negligible number

Table.6 Mean number of moths trapped

\begin{tabular}{|l|l|}
\hline Trap Type & No. of Moths trapped \\
\hline Water trap & 9.50 \\
\hline ICRISAT funnel trap & 4.25 \\
\hline Rao's funnel trap & 0.00 \\
\hline TDRI funnel trap & 2.00 \\
\hline Delta sticky trap (Small) & 0.25 \\
\hline Delta sticky trap (Large) & 6.00 \\
\hline
\end{tabular}

Mukunthan et al., (2003)

\section{Pest management}

Among the biotic stresses, pests and diseases pose a major threat to sugarcane cultivation. Nearly 210 insect pests are reported to infest the crop, of which borers and sucking pests are of economic importance (Salin and Srikanth, 2011).
Strict plant quarantine preventing pests from artificially spreading

Plant quarantine, also called regulation control, is to check agricultural product, seeds, seedlings via laws while their transportation. The purpose is to prevent dangerous pests, diseases and weeds to spread 
by imports. The transport of sugarcane seed canes must be examined, and the transport must be stopped or the seed canes must be deal with strict quarantine regulations appropriately when dangerous organisms are found. For example, soaking the seeds 24-48 $\mathrm{h}$ with 2 per cent limewater is an effective method for removal of pests from sugarcane seeds (Wei, 1996; Feng, 2003).

\section{Botanicals}

Field studies reveal that aphid's mortality was gradually increased from 24 hours to $92 \mathrm{hrs}$. As observed in the laboratory bioassay, field experiment confirms the in-vitro experiments. Among the four plants maximum mortality was recorded in A. concianna followed by $M$. charantia, A. calamus and A. squamosal, Acacia concianna appear to be promising botanical insecticide against Ceratovacuna lanigera Zehnter and may hold potential for identification of new lead structures (naturally obtained compounds, organic farmers could use them but they also could be used in association with organic synthetic pesticides in insecticide soaps. Their incorporation within insecticidal formulations could increase the number of biochemical targets in the insects, limiting prospect for the onset of resistance and offering the prospect of reducing pesticide dose (Regnault-Roger et al., 2004).

\section{Crop rotation and intercropping}

Sugarcane should be avoided to intercropped with cereals such as corn and sorghum in order to prevent the pests spreading between sugarcane and other cereal crops. Sugarcane should be encouraged to intercropped with legumes or green manure crops and vegetables, such as peanut, soybean, mung bean, legume green manure crops, tomato, hot pepper, Chinese cabbage, etc. The intercropping can increase the farmer's income and also can improve the miniclimate in the field, creating an ecological environmental balance suitable to the survival of parasites and red, acing the damage of pests and diseases (Wei, 1996; Wang, 2002; Feng, 2003). In the same field, if, sugarcane is grown for successive years, borers will have numerous overwintering populations, and the processes of borer development will be asynchronous, the borer occurrence will be heavy, causing severe damage. So crop rotation between sugarcane and non-cereal crops such as soybean is encouraged. In the on-farm trial with soybean as intercrop, the differences in shoot borer incidence between intercrop and monocrop varied with the age of the crop. In the 25 days old crop, the incidence was significantly $(\mathrm{P}<0.001)$ higher in intercrop (range: $3.9-12.6 \%$ ) than in monocrop (range: 0.2 - 1.3\%) (Srikanta et al., 2000). In most intercrop studies analysed, pest abundance was less in intercrop (Risch, 1983) which is, generally, short in stature and duration. In sugarcane-based intercrop systems, such reductions were noticed in cotton (Wankhede and Parashar, 1975), beans (Garcia et al., 1979) and potato (Parihar and Singh, 1992) (Table 5).

\section{Technique of mass trapping pheromone}

During the copulation period, installing certain amount of traps of sexy tube can attract male moth and kill large amount of male moths, which will result in disproportion of the moths between the male and the female in the fields so most of the female moths cannot find the chance to mate. In this case the next generation density will decrease (You et al., 1999; Yang et al., 1999). In trials on mass trapping of male moths with pheromone lures using water traps, a total of 80,603 moths were caught during May February from a 10.0 ha plot in Pugalur, Tamil Nadu. The intensity of attack in that plot was significantly less and the cane yield 
and CCS/plot were significantly more in treated plots compared to the check plot (David et al., 1985). The pheromone vial in the water trap simulated the virgin female and was deployed in the centre of the treated plots. The per cent reduction in the number of moths caught in the traps of treated plots over the control plot determined the efficacy of the communication disruption or confusion technique. The results indicated that both the inhibitor and the attractants were equally effective in preventing 46.8 per cent of moth from reaching the vials simulating the virgin females. To further improve the efficacy and to have a long lasting effect of the inhibitor or the attractant in the field and due to the difficulty in spraying the microencapsulated formulations, adhesive flakes of the inhibitor and attractants were tried. The flakes each of approximately one $\mathrm{cm}^{2}$ were distributed at the rate of one flake per clump.

The flakes had improved efficacy with 76 per cent reduction in moth catches which however was below 99 per cent efficacy required for mating disruption technique (Curtis et al., 1987). The pheromones of top borer have been identified in China as (E)-I 1hexadecenal and (z)-I 1-hexadecenal. They have been reported effective against top borer at 78:22 and 70:30 (Liu, 1992) ratios. So the efficacy of both the ratios was tested by Sugarcane Breeding Institute. The Plant Research International, the Netherlands readily supplied free samples of lures of both the formulations impregnated at one $\mathrm{mg}$ concentration in rubber septa as per our request. The preliminary field studies at Harinagar Sugar Mills Ltd., Bihar, have revealed that 70:30 ratio is significantly more effective [' $\mathrm{t}$ ' value at 0.05 for $66 \mathrm{df}=2.462$ ] trapping an average of $10.29 /$ day. The work is in progress to indegenise the lures, to improve the trap catch by increasing the dose per septum and to evaluate the efficacy of different dispensers (Table 6).

\section{Economics}

The highest net profit and benefit: cost (B: C) ratio were recorded in autumn - planted cane with FYM 20 t/ha Trichoderma viride + lentil intercropping. In spring planted cane the highest net profit and $\mathrm{B}$ : $\mathrm{C}$ ratio was recorded with FYM 20 t/ha + Trichoderma viride + mungbean intercropping. These were closely followed by autumn and spring - planted cane with SPM 10 t/ha + FYM 10 t/ha (Srivastava et al., 2008). Application of FYM @ 20 t/ha significantly increased the net return and benefit: cost ratio (2.16) and the increase in net return and benefit: cost ratio due to FYM over control was 26.3 and 8.5 respectively (Kumar, 2012). Shirsagar (2008) studied the impact of organic farming on economics of sugarcane cultivation in Maharashtra. The study was based on primary data collected from two districts covering 142 farmers, 72 growing Organic Sugarcane (OS) and 70 growing Inorganic Sugarcane (IS). The results concluded that OS cultivation enhances human labour employment by 16.9 per cent and its cost of cultivation is also lower by 14.2 per cent than IS farming. Although, the yield from OS was 6.79 per cent lower than the conventional crop, it is more than compensated by the price premium received and yield stability observed on OS farms. Overall, the OS farming gave 15.63 per cent higher profits than IS farms (Table 4).

To maintain the productivity of sugarcane at a high level on a long-term basis it is necessary to evolve a system whereby adequate supplies of organic manures and biofertilizers. Organic manures and biofertilizers application in the nutrient management programme is inevitable for achieving sustainable sugarcane production. Application of FYM, cane trash, pressmud, vermicompost and biocompost in combination with recommended inorganic fertilizers have recorded increased cane yield over inorganic fertilizer alone, besides 
improving the soil fertility and economizing the cane production. Intercropping and incorporation of green manures such as daincha, sunhemp have established beneficial effects of improving nitrogen use efficiency, cane yield and improving the physio-chemical properties of soil. Nitrogen fixing biofertilizers' are useful to economise the nitrogenous fertilizers and to increase the cane yield. Phosphorus solubilising biofertilizers solubilize the unavailable phosphorus to available $\mathrm{P}$ form and increase the $\mathrm{P}$ use efficiency. Inclusion of biofertilizers in the nutrient management programme has found to increase the yield of sugarcane by 5 $10 \%$, besides increasing the nutrient use efficiency.

\section{References}

Feng, Y.X. (2003). Superficial view to the integrated control of sugarcane diseases and pests in Zhangjiang. Sugarcane and Canesltgut. 2: 28-29.

Gana, A. K. and Busari, L. D. (2006). Contribution of green and farm yard manure in the nitrogen nutrition of sugarcane. Sugar Tech., 8 (2\&3): 175179.

Giraddi, R. S. (1993). Vermiculture and its role in agriculture. In: Proc. of course on use of bio-fertilizers. Training programme for the officers of state Department of Agriculture, Karnataka, 18-21 October, 1993 by the University of Agricultural Sciences, Dharwad, pp. 50-54.

Kumar, N. (2012). Productivity, quality and nutrient balance in spring sugarcane (Saccharum spp. hybrid complex) under organic and inorganic nutrition. Ind. J. Agronomy 57 (1): 68-73.

Kumar, V. and Sagwal, O. P. (1998). Effect of sugarcane trash and fertilizer nitrogen applications on the nutrient status and soil physical properties in
Haryana soil. Indian Sugar 47: 967-971.

Kumar, V., Preveen, K. and Dalip, K. (2005). Ganay Ki Adhik Padavar Thatha Tikau Kheti ke Leay Karbonicavaen javik Khado ka paryog. Khad Patritrika. October 2005 (In Hindi). pp29-32

Kumaraswamy, K. (1995). Recycling of sugarcane trash as enriched manure for sustaining productivity of sugarcane lands. Paper presented at the $28^{\text {th }}$ meeting of the sugarcane research and development workers of Tamil Nadu held at Kumbakonam (Tamil Nadu) November, 15-16, 1995, pp. 12-15.

Parameswaran, P., Durai, R. and Sankaran, K. (1995). Measures for augmenting organic matter in sugarcane soil. Paper presented at the 28th Meeting of Sugarcane Research and Development Workers of Tamil Nadu held at Kumbakonam November, 15-16, 1995.

Patil, D. S. and Chavan, N. S.(2009). Bioefficacy of some botanicals against the sugarcane woolly aphid, Ceratovacuna lanigera Zehnter. $J$. Biopesticides. 2(1): 44-47.

Paturau, J. M. (1984). By-products of the cane sugar industry. 2nd edition, Elsevier, Amsterdam, p: 365.

Saini, S. K., Rajesh, A., Vijendar Singh. and Sinha, S. K. (2006a). Effect of fly ash, press mud cake and phosphorus solubilising bacteria (PSB) on yield, growth and quality of sugarcane. Indian Sugar, 56: 25-28.

Salin, K. P. and Srikanth, J. (2011). Borers and sucking pests of sugarcane. In: T. Rajula Shanthy and N. V. Nair (Eds), Crop protection technologies in sugarcane: pp.106 111.

Shankaraiah, C. and Kalyanamurthy, K. N. (2005). Effect of enriched press mud cake on growth, yield and quality of sugarcane. Sugar Tech., 7(2\&3), 1-4.

Sharma, B. L., Sujeet Pratap Singh, Singh, D. N., Singh, R. R. and Singh, S. B. 
(2005b). Effect of neem cake in conjunction with insecticides on sugarcane in calcareous soils, Cooperative Sugar 37(3): 41-46.

Shirsagar, K. G. (2008). Impact of organic farming on economics of sugarcane cultivation in Maharashtra, Gokhale Institute of Politics and Economics, Pune, pp.15.

Singh, K. P. and Srivastava, T. K. (2011). Sugarcane productivity and soil fertility in plant -ratoon system under integrated and organic nutrient management in sub-tropics. Ind. J. Sugarcane Tech., 26(1):10-13.

Singh, S. K. and Katiyar, A. (2016). The economic importance of sugarcane: an imperative grass of Indian subcontinent. J. Exp. Zoo., 19 (1): 401-406.

Sinha, S. K., Jha, C. K., Vipin, K., Geeta, K., and Alam, M. (2014). Integrated effect of biocompost on soil properties, juice quality and yield of sugarcane in vertisol., Sugar Tech. 16(1): 75-79.

Vedprakash, Mangey Ram and Lal, K. (2009). Effect of continuous application of organic manure and inorganic fertilizers on yield and quality attributes of sugarcane. Cooperative Sugar, 40(7): 65-67.
Wei, J.M. (1996). Damage and control of sugarcane borers. Hunan Agricul. Sci., (Suppl.), 34-35.

Yadahalli, K. B. (2008). Influence of Organic amendments on Sugarcane set rot development. International J. Plant Sci. Muzaffaranagar, 3(2): 556-557.

Yadav, D.V. (1995). Recent trends in the utilization of press mud cake in Indian agriculture. In Sugarcane AgroIndustrial Alternatives. Eds G.B. Singh and S. Solaman. Oxford and IBH Publishing Co-Pvt. New Delhi.

Yogananda, S. B., Thimmegowda, M. N., Murthy, K. R. and Ravindrababu, B. T. (2014a). Growth and yield of sugarcane as influenced by different plant nutrients. In: Proc. of the Natl. Sem. on Recent Advances and Challenges in Sugarcane Research, 23-24 January, Mysore, India. p. 83.

Yogananda, S. B., Thimmegowda, M. N., Murthy, K. R. and Ravindrababu, B. T. (2014b). Yield performance of sugarcane as influenced by different levels of farmyard manure and biodigester liquid. In: Proc. of the Natl. Sem. On Recent Advances and Challenges in Sugarcane Research, 2324 January, Mysore, India, p. 86.

\section{How to cite this article:}

Shilpa V. Chogatapur, Vishwajith and Reshma Sutar. 2017. Organic Sugarcane: A Review. Int.J.Curr.Microbiol.App.Sci. 6(12): 1729-1738. doi: https://doi.org/10.20546/ijcmas.2017.612.196 